\title{
SALICORNIA PLANTS GROWTH AND YIELD AS AN INDICATOROF SALT STRESS CONDITIONS
}

\author{
Rabeh, A. Abdu ${ }^{(1)}$; Hesham I. El-Kassas ${ }^{(2)}$ \\ Saeed A. El-Desouky ${ }^{(3)}$
}

1) Post graduate student at Institute of Environmental Studies \& Research, Ain Shams University 2) Institute of Environmental Studies \& Research, Ain Shams University 3) Faculty of Agriculture, Benha University

\begin{abstract}
Salt stress became the most challenge for agriculture production and development. Two practical trials were carried out in a private farm at Abdo Basha Village, Kafr El-Dawwar, Behaira Governorate during two winter growing seasons 2017 and 2018 seasons to study the effect of the irrigation levels with salt water i.e., (9000, 18000, 24000 and 36000 ppm of water salinity and Nile water as control) on growth, yield and accumulation of salt in different plant parts of Salicornia grown in boxes in cultivated soil.

Results indicated that plant height, leaves number, number of branches, fresh and dry weights of shoots increased with increasing salt water levels at 80,120,150 and 180 days of plant age during 2017 and 2018 seasons. Also, root growth characteristics i.e., root length, fresh ad dry weights were increased with increasing salt water levels at 80,120,150 and 180 days of plant age during 2017 and 2018 seasons. Yield and seed yield were increased with salt water levels during 2017 and 2018 seasons. Different salt irrigation water levels i.e., 9000 ppm salt water, 18000 ppm salt water, 24000 ppm salt water and $36000 \mathrm{ppm}$ salt water) decreased salt concentration (ppm) in soil at $0,80,120,150$ and 180 days of plant age during 2017 and 2018 seasons. The control gave the lowest value for soil salt concentration (ppm) at different plant stages during the two growing seasons. Increasing salt water levels decreased salt concentration in soil attributed to the salt water percentage during plant life time in both seasons. The most beneficial treatment for


increasing yield and its components and decreasing the salt from the soil was that $36000 \mathrm{ppm}$ of salt water during first and second seasons.

Key words: Salicornia plants, Salt water, growth characteristics, yield.

\section{INTRODUCTION}

High salinity, one of the most harmful environmental stresses for plants, limits the productivity and growth of food and feed crops on cultivated and Irrigated land worldwide (Isca et al., 2014; Patel, 2016 and Roy et al., 2014).In this respect, Previous studies have shown that increased salinity not only results from residual sea water but also, from the accumulation of artificial fertilizers or natural resources from cluster minerals (Munns \& Tester, 2008; Roy et al., 2014 and Zhu, 2001).

The primary cause of this salinity stress is an increase in sodium $(\mathrm{Na}+)$ and chloride $(\mathrm{Cl}-)$ ions, the most abundant salt ions in natural sources (Jaleel et al., 2007; Shabala \& Mackay (2011), Aghaleh et al., 2009; Nie et al., 2015). Salinization is the process of increasing the concentration of total dissolved salts in soil and water either due to natural processes (primary salinization) or anthropogenic actions (secondary salinization) (Ghassemi et $a l ., 1995)$.The process of secondary salinization is exacerbated by the use of saline ground water and poor quality waste water for irrigation, as well as by clearing deep-rooted forest lands for pasture and crop production (Lambert \& Turner, 2000 and Barrett- Lennard, 2002). Globally, irrigated land represents only $15 \%$ of the total cultivated land but produces one third of the world's food (Munns, 2005).On average, it is estimated that about 100Mha of land 
have become saline due to irrigation (Ghassemi et al., 1995; Pessarakli \& Szabolics, 1999), so about $11 \%$ of the world's irrigated areas are already affected by some degree of salinization (FAO, 2012). Alarmingly, the amount of salt-affected land and its continuous expansion is highest in some of the most populated and economically challenged countries such as Bangladesh.

Halophytes are naturally evolved salt-tolerant plants that represent at most $2 \%$ of terrestrial plant species (Flowers \& Colmer, 2008). They have the ability to complete their life cycle in a NaCl- rich environment where almost $99 \%$ of salt sensitive species die because of $\mathrm{NaCl}$ toxicity, and thus may be regarded as a Source of potential new crops (Glenn et al., 1999). Although halophytes have been recognized for hundreds of years, their definition remains equivocal (Flowers and Colmer, 2008).

Halophytic species possess a range of highly efficient and complementary morphological, physiological and anatomical characteristics to combat and even benefit from a saline environment (Flowers et al., 1977; Flowers \& Colmer, 2008 and Shabala \& Mackay, 2011). In Egypt, the halophytic grasses Leptochloafusca, Spartina patens and S. virginicus are used for forage production. Their dry matter (DM) yield ranged between 1.1 and $6.5 \mathrm{t}$ $\mathrm{DM} / \mathrm{ha} /$ year making them ideal as for- age crops in the desert areas where only saline water is available for irrigation (Ashour et al., 1999).Salicornia have been tested as fodder crops as renewable energy sources (biofuel) for phytoremediation (Eganathan et al., 2006), as landscaping ornamentals and as food for human consumption (Ventura et al., 2011).Salicornia is used as 
traditional medicine treating hypertension, cephalalgia and scurvy In Korea, it is used in the treatment of constipation, obesity, diabetes and cancer. The purpose of this work was to investigate the possibility of including the halophyte Salicornia in life support systems (in simulation experiments) in order to involve $\mathrm{NaCl}$ in the material cycling and to estimate the effect produced by substrate salinization and light intensity on the $\mathrm{NaCl}$ uptake by Salicornia plants as an indicator for salt stress conditions.

\section{MATERIAL AND METHODS}

The experimental part of this study was carried out in a private farm at Abdo Basha Village, Kafr El-Dawwar, Behaira Governorate during two winter growing seasons of 2017 and 2018 to study, the effect of irrigation levels with salt water i.e., (9000, 18000, 24000 and 36000 ppm salt water and Nile water as a control 200 ppm) on growth, yield and accumulation of salts in different plant parts. Alsoto determine the beneficial effects of Salicornia plants as an indicator to the salt conditions. Soil of the experiment was collected from salt Daline soil in Abdo Basha Village, Kafr El-Dawwar, Bahira Governorate and distributed in boxes, then sown Salicornia seeds. Uniform seeds of Salicornia plants (10 gr/box) were sown regularly each for depth and the distance between each treatment was arranged in five replicates for each group, i.e. 25 boxes for all treatments. Then, boxes were irrigated every three days with 8 liter (field capacity)of its assigned salt water level (as previously mentioned). This amount of water was continued until the end of 198 
February in both seasons then it was increased to twelve liters /box until the last two weeks before the harvest. Also, there were no fertilizers added during the experiment growing seasons. All other agriculture cultural practices were performed as recommended.

Physical and chemical properties of the experimental Soil: Soil samples were air-dried, crushed, passed through a $2 \mathrm{~mm}$ sieve and analyzed for various physicochemical properties. Physical and chemical properties of the experimental soil were determined as follows:

Mechanical analysis was determined using the international pipette method according to Piper (1950).

Table (1): Physical and chemical properties of the experimental soil during 2017 and 2018 seasons

\begin{tabular}{|c|c|c|c|c||}
\hline Soil & $\begin{array}{c}\text { Soil } \\
\text { Texture }\end{array}$ & $\mathbf{p H}$ & SP & $\begin{array}{c}\text { Salt concentration } \\
\text { ppm }\end{array}$ \\
\hline \hline 2017 & sandy loam & 7.9 & 40 & 12350 \\
\hline 2018 & Clay loam & 8.1 & 40 & 19280 \\
\hline
\end{tabular}

Seeds source: Salicornia seeds were collected from shrubs growing in Odiel salt marshes. Fruits were collected from plants in various salt pan populations. These salt marshes are under the influence of the Mediterranean climate and affected by oceanic influences. Winter is wet and with mild temperatures and summer is long and dry. Mean annual precipitation is $6 \mathrm{~mm}$ with an interannual variation coefficient of $31 \%$. 
Source of salt water: Salt water was prepared dissolving by $\mathrm{NaCl} 36 \mathrm{~g} / \mathrm{l}$ as a source of salt (36.000 ppm). Treatments of salt water composite of different concentrations of salt water and fresh Nile water were as follows: $\mathrm{T}^{0}$ (Nile water as control, $200 \mathrm{ppm}) ., \mathrm{T}^{1}(25 \% 6 \mathrm{~g} / 1 \mathrm{NaCl}$ to make $9000 \mathrm{ppm}) ., \mathrm{T}^{2}$ $(50 \% 18 \mathrm{~g} / 1 \mathrm{NaCl}$ to make $18000 \mathrm{ppm}) ., \mathrm{T}^{3}(75 \% 24 \mathrm{~g} / \mathrm{l} \mathrm{NaCl}$ to make $24000 \mathrm{ppm})$ and $\mathrm{T}^{4}(100 \% 36 \mathrm{~g} / \mathrm{l} \mathrm{NaCl}$ to make $36000 \mathrm{ppm})$.Percentages of seedling emergence, three weeks after sowing the number of emerged seedlings for each box was counted in different treatments. Percentages of seedling emergence were counted by dividing the number of emerged seedlings by the number of sown seeds (i.e., $10 \mathrm{~g}$ ). Then seedlings were trimmed by ten plants for each box. Seeds were sown $(10 \mathrm{gr} / \mathrm{box})$ at $10^{\text {th }}$ of December in $2017 / 2018$. The box area was (100x50x50 cm in diameter) and the treatments were distributed in Randomized Complete Block Design (RCBD) with five replicates.

\section{Sampling and collecting data:}

(I) Growth characteristics: Growth characteristic measurements were collected and measured at (80, 120, 150 and 180 days) after sowing during 2017 and 2018 seasons. The following parameters were measured or estimated:

Root length $(\mathrm{cm})$., plant height $(\mathrm{cm})$., Number of leaves/plant., Number of branches / plant., Root fresh weight g/plant, Shoots fresh weight g/plant., Dry weight of shoots g/plant. 
(II) Yield characteristics: Ten random plant samples of each treatment were chosen to measure and determine the final growth and yield characteristics. The following data were collected.

(III) Final yield characteristics: Seed weight g/plant., Dry weight of straw $\mathrm{g} /$ plant., the number of seeds in $1 \mathrm{~g}$.

(IV) Soil Salt concentration, ppm: Soil Salt concentration (ppm) was determined in soils at $0,80,120,150$ and 180 days after sowing in the experimental soil. Electrical conductivity in 1:2:5 soil water extract was determined according to Black (1965).

(V) Statistical analysis: Data of morphological, flowering and yield characteristics were statistically analyzed and the means were compared using the Least Significant Difference test (L.S.D) at 5\% levels according to Snedecor and Cochran (1980).

\section{RESULTS AND DISCUSSION}

(I) Effect of salt water on Salicornia seed germination: Data presented in Table 2 indicated that the optimal germination of seeds of Salicornia occurred in distilled water treatments. Salinity increments inhibited germination of seeds. The smallest decrease in germination was obtained from T3 treatment. There was no seed could germinate in T4 solutions.

Also, Table (2) illustrates the percentage germination of seeds incubated for 20 days in salt solutions ranging from $\mathrm{T} 0$ to $\mathrm{T} 3$. These data indicate that the germination of seeds were decreased with increasing of water salinity. 
Abdu et al.

Table (2): Effect of salt water levels on Salicornia germination characteristics during 2017 and 2018 seasons at $25 \mathrm{C}^{\mathrm{o}}$

\begin{tabular}{|c|c|c|}
\hline \multirow{2}{*}{$\begin{array}{c}\text { Charach. } \\
\text { Treatment }\end{array}$} & $\mathbf{2}$ & Germination \% \\
\cline { 2 - 3 } & 85.0 & $\mathbf{2 0 1 8}$ \\
\hline T0 & 69.0 & 86 \\
\hline T1 & 46.0 & 70.0 \\
\hline T2 & 35.0 & 47.0 \\
\hline T3 & 0.0 & 36.0 \\
\hline T4 & 2.00 & 0.0 \\
\hline L.S.D. at 5 \% & \\
\hline
\end{tabular}

T0 control (Nile water); T1 (salt water 9000 ppm); T2 (salt water 18000 ppm);

T3 (salt water 24000 ppm) and T4 (salt water (36000 ppm).

(II) Effect of irrigation by salt water levels on growth characteristics of

\section{Salicornia plants during different plant stages:}

- At 80 days of plant age: Data in Table (3) indicated that increasing levels of irrigation water salinity i.e.,( 0, 9000, 18000, 24000 and 36000 ppm) significantly increased plant height $\mathrm{cm}$, root length $\mathrm{cm}$, Num. of leaves /plant, Num. of branches /plant, Root fresh and dry weights g/plant, shoots fresh and dry weights g/plant when compared with the control (irrigated with river water) at 80 days of plant age during 2017 and 2018 seasons. It could be noticed that that the level of $18000 \mathrm{ppm}$ of salt water gave the highest values of estimated or measured characteristics, i.e., plant height, root length, number of leaves/plant, number of branches and shoot dry weight. Since, these parameters gave respectively the values of 70.1, 67.98 202

Vol.(49); Iss.(8); No.(4); August 2020 
Journal of Environmental Sciences (JES)

Institute of Environmental Studies and Research, Ain Shams University

Abdu et al.

for plant height; 17.16 and 16.28 for root length; 23.00, 22.00, for leaves number ; 23.66,21.00, for number of branches;85.74,80.39 for roots fresh weights;197.75,190.69 for shoots fresh weights and 101.11,92.74 for shoots dry weights during 2017 and 2018 seasons, respectively. Also, it could be noticed that the level of 24000 ppm salt water ranked the second significantly increasing in the assigned treatments. In addition, the most pronounced results is that the salt water increased in ascending order the fresh and dry weights of treated plants to reach its maximum with T4 i.e., $36000 \mathrm{ppm}$ of water salt. These results confirm the fact that salinity led to more accumulation for dry matter including sources of salinity absorbed from soil by the growing Salicornia plants In context shoots fresh and dry weight g/plant gave the highest value with 36000 ppm salt water, followed by 24000 ppm salt water, followed by 18000 ppm salt water, followed by 9000 ppm salt water when compared with the control treatment at 80 days after sowing during 2017 and 2018 seasons.

In this respect the obtained increase of these traits with salt water levels could attributed to the alleviate of salt water by Salicornia plants by increasing its ability to accumulated salt in different parts during plant growth and development. These results are in agreement with those working on alleviation of salt water by Salicornia and other plants,(Tobe, et al (2004), Song, et al (2008) and Singh et al., (2014). 
Table (3): Effect of irrigation by salt water levels on some growth characteristics of Salicornia plants at 80 days of plant age during 2017 and 2018 seasons

\begin{tabular}{|c|c|c|c|c|c|c|c|c|c|c|c|c|c|c|}
\hline $\begin{array}{l}\text { Charach. } \\
\text { Treatment }\end{array}$ & plant I & $\begin{array}{l}\text { height, } \\
\text { m }\end{array}$ & Root le & ngth, & $\begin{array}{r}\text { Num. } 0 \\
\text { pl }\end{array}$ & $\begin{array}{l}\text { leaves } \\
\text { nit }\end{array}$ & $\begin{array}{r}\text { Num } \\
\text { branche }\end{array}$ & $\begin{array}{l}\text { 1. of } \\
\mathrm{s} / \text { plant }\end{array}$ & $\begin{array}{l}\text { Roots } \\
\text { weight }\end{array}$ & $\begin{array}{l}\text { (fresh } \\
\text { g/plant }\end{array}$ & $\begin{array}{l}\text { Shoot } \\
\text { weight }\end{array}$ & $\begin{array}{l}\text { fresh } \\
\text { g/plant }\end{array}$ & $\begin{array}{l}\text { Sho0 } \\
\text { weight }\end{array}$ & $\begin{array}{l}\text { Dry } \\
\text { plant }\end{array}$ \\
\hline & 2017 & 2018 & 2017 & 2018 & 2017 & 2018 & 2017 & 2018 & 2017 & 2018 & 2017 & 2018 & 2017 & 2018 \\
\hline T0 & 42.18 & 40.15 & 11.331 & 10.22 & 18.33 & 16.33 & 9.00 & 8.66 & 52.21 & 46.12 & 109.21 & 100.69 & 61.23 & 42.25 \\
\hline $\mathrm{T} 1$ & 61.11 & 55.36 & 15.41 & 13.39 & 22.66 & 20.66 & 14.33 & 12.33 & 68.58 & 66.54 & 115.41 & 110.48 & 57.02 & 51.89 \\
\hline $\mathrm{T} 2$ & 70.10 & 67.98 & 17.16 & 16.28 & 23.00 & 22.00 & 23.66 & 21.00 & 85.74 & 80.39 & 197.75 & 190.69 & 101.11 & 92.74 \\
\hline $\mathrm{T} 3$ & 63.70 & 60.78 & 15.91 & 14.74 & 21.33 & 20.33 & 18.00 & 17.66 & 79.15 & 72.78 & 260.14 & 250.78 & 141.12 & 112.84 \\
\hline $\mathrm{T} 4$ & 55.52 & 52.61 & 14.98 & 13.58 & 22.00 & 19.66 & 17.33 & 16.33 & 82.62 & 78.69 & 321.95 & 310.69 & 180.86 & 186.38 \\
\hline LSD 5\% & 1.22 & 1.33 & 1.11 & 1.55 & 0.66 & 1.25 & 0.33 & 2.62 & 1.49 & 1.56 & 1.45 & 2.33 & 1.36 & 1.58 \\
\hline
\end{tabular}

T0 control (Nile water); T1 (salt water 9000 ppm); T2 (salt water 18000 ppm);

T3 (salt water $24000 \mathrm{ppm}$ ) and T4 (salt water (36000 ppm).

- At 120 days of plant age: In Table (4)data clearly indicate that plant height $\mathrm{cm} /$ plant, root length $\mathrm{cm} /$ plant were increased with irrigation of salt water levels i.e., (9000, 18000 ,24000 and 36000 ppm) when compared with the control (Nile water) at 120 days of plant age during 2017 and 2018 seasons. The highest values of those traits were $9000 \mathrm{ppm}$ from salt water which gave $89.90,82.66,21.11,19.71$ stem height and root length respectively, during 2017 and 2018 seasons, followed by 18000 ppm salt water followed by $24000 \mathrm{ppm}$ salt water, followed by $36000 \mathrm{ppm}$ salt water when compared with the control, it gave lowest value at 120 days of 
plant age during both seasons. In the same time number of leaves/plant decreased with application of salt water levels when compared with the control during first and second seasons. Number of branches /plant, roots fresh weight $(\mathrm{g}) /$ plant, shoots fresh weight $(\mathrm{g}) /$ plant and shoots dry weights (g)/plant significantly increased with application of 36000 ppm salt water followed by $24000 \mathrm{ppm}$ salt water, followed by $18000 \mathrm{ppm}$ salt water followed by 9000 ppm salt water when compared with the control (Nile water) at 120 days of plant age during 2017 and 2018 seasons.

Salicornia from halophytes, it grows as saltresistant or salt-tolerant plants which can grow in moderate to high saline soil by utilizing salinity for their growth, Greenway \& Munns (1980). Halophytes can be obligatory halophytes, preferential halophytes, supporting halophytes, accidental halophytes, obligatory halophyte (Salicornia brachiata) require salinity for survival as well as optimum growth. The halophyte Salicornia brachiataRoxb belongs to the Amaranthaceous family. 
Table (4): Effect of irrigation by salt water levels on some growth characteristics of Salicornia plants at 120 days of plant age during 2017 and 2018 seasons

\begin{tabular}{|c|c|c|c|c|c|c|c|c|c|c|c|c|c|c|}
\hline \multirow{2}{*}{$\begin{array}{l}\text { Charach. } \\
\text { Treatment }\end{array}$} & \multicolumn{2}{|c|}{$\begin{array}{l}\text { plant height, } \\
\text { cm }\end{array}$} & \multicolumn{2}{|c|}{$\begin{array}{l}\text { Root length, } \\
\text { cm }\end{array}$} & \multicolumn{2}{|c|}{$\begin{array}{c}\text { Num. of leaves } \\
\text { plant }\end{array}$} & \multicolumn{2}{|c|}{$\begin{array}{c}\text { Num. of } \\
\text { branches/plant }\end{array}$} & \multicolumn{2}{|c|}{$\begin{array}{l}\text { Roots (fresh } \\
\text { weight) } g \text { plant }\end{array}$} & \multicolumn{2}{|c|}{$\begin{array}{l}\text { Shoot (fresh } \\
\text { weight) g/plant }\end{array}$} & \multicolumn{2}{|c|}{$\begin{array}{c}\text { Shoots Dry } \\
\text { weight g/plant }\end{array}$} \\
\hline & 2017 & 2018 & 2017 & 2018 & 2017 & 2018 & 2017 & 2018 & 2017 & 2018 & 2017 & 2018 & 2017 & 2018 \\
\hline $\mathrm{T} 0$ & 699.24 & 65.22 & 17.10 & 15.12 & 31.00 & 27.00 & 12.00 & 10.00 & 190.11 & 1771.22 & 199.71 & 192.59 & 98.16 & 90.11 \\
\hline $\mathrm{T} 1$ & 89.90 & 82.66 & 21.11 & 19.71 & 24.33 & 21.33 & 14,33 & 11.33 & 191.32 & 182.42 & 289.11 & 271.69 & 151.48 & 132.41 \\
\hline $\mathrm{T} 2$ & 83.22 & 79.18 & 20.17 & 18.68 & 29.66 & 25.66 & 25.66 & 23.66 & 199.41 & 189.78 & 352.45 & 335.47 & 181.52 & 160.98 \\
\hline $\mathrm{T} 3$ & 75.51 & 70.39 & 19.11 & 16.19 & 24.33 & 21.00 & 27.00 & 25.00 & 205.61 & 200.69 & 471.87 & 452.89 & 245.60 & 210.30 \\
\hline $\mathrm{T} 4$ & 71.69 & 65.36 & 14.91 & 13.48 & 23.00 & 22.33 & 29.66 & 27.66 & 217.45 & 210.37 & 690.71 & 668.69 & 380.76 & 351.82 \\
\hline LSD $5 \%$ & 1.64 & 1.55 & 1.36 & 2.15 & 1.00 & 1.66 & 1.00 & 0.33 & 1.75 & 1.78 & 2.32 & 3.15 & 1.42 & 1.36 \\
\hline
\end{tabular}

T0 control (Nile water); T1 (salt water 9000 ppm); T2 (salt water 18000 ppm);

T3 (salt water 24000 ppm) and T4 (salt water (36000 ppm).

- At 150 days of plant age: As shown in Table (5) the applied treatments i.e. the irrigation levels with salt water at 9000, 18000, 24000, 36000 ppm and normal water $=$ Nile water, $200 \mathrm{ppm}$ as control obviously affected plant height, root length, leaves number, branches number, fresh weight of roots and shoots and dry weight of shoots at 150 days of plant age during 2017 and 2018 seasons. Actually, plant height, root length and number of leaves /plant reached the highest values with $9000 \mathrm{ppm}$ salt water followed by 18000 ppm salt water, followed by $24000 \mathrm{ppm}$ salt water followed by 36000 ppm salt water when compared with the control at 150 days of plant age during 2017 and 2018 seasons. Meanwhile, Num. of branches /plant 
and root weight $(\mathrm{g})$ per plant significantly increased with different applied treatments and reached the highest value with $36000 \mathrm{ppm}$ salt water followed by 24000 ppm, 18000 ppm and 9000 ppm salt water at 150 days of plant age during 2017 and 2018 seasons. In the same time shoot fresh weight $\mathrm{g} /$ plant, shoot dry weight $\mathrm{g} /$ plant reached the highest value with salt water at $24000 \mathrm{ppm}$ followed by $36000 \mathrm{ppm}$, followed by $18000 \mathrm{ppm}$, followed by 9000 ppm salt water when compared with the control (Nile water, 200 ppm) at 150 days of plant age during 2017 and 2018 seasons.

In general salt water with different levels, affected growth characteristics of Salicornia plants at 150 days after sowing during 2017 and 2018 seasons.

In this respect, the alleviation of salt water on growth behavior of Salicornia plants could be attributed to tolerance of the plant to salts and accumulation of salts in different plant parts during plant growth and development. 
Table (5): Effect of irrigation by salt water levels on some growth characteristics of Salicornia plants at 150 days of plant age during 2017 and 2018 seasons

\begin{tabular}{|c|c|c|c|c|c|c|c|c|c|c|c|c|c|c|}
\hline \multirow[b]{2}{*}{ Treatment } & \multicolumn{2}{|c|}{$\begin{array}{c}\text { plant height, } \\
\text { cm }\end{array}$} & \multicolumn{2}{|c|}{$\begin{array}{l}\text { Root length, } \\
\text { cm }\end{array}$} & \multicolumn{2}{|c|}{$\begin{array}{c}\text { Num. of } \\
\text { leaves /plant }\end{array}$} & \multicolumn{2}{|c|}{\begin{tabular}{|c|} 
Num. of \\
branches/plant
\end{tabular}} & \multicolumn{2}{|c|}{$\begin{array}{c}\text { Roots (fresh } \\
\text { weight) g/plant }\end{array}$} & \multicolumn{2}{|c|}{$\begin{array}{c}\text { Shoot (fresh } \\
\text { weight) } g / \text { plant }\end{array}$} & \multicolumn{2}{|c|}{$\begin{array}{c}\text { Shoots Dry weight } \\
\text { g/plant }\end{array}$} \\
\hline & 2017 & 2018 & 2017 & 2018 & 2017 & 2018 & 2017 & 2018 & 2017 & 2018 & 2017 & 2018 & 2017 & 2018 \\
\hline $\mathrm{T} 0$ & & 85.11 & 26.05 & 21.56 & 18.00 & 16.33 & 13.00 & 11.33 & 205.98 & 195.18 & 1310.11 & 22 & 710.11 & 660.47 \\
\hline T1 & & 91.55 & 29.11 & 23.69 & 23.33 & 24.66 & 11.66 & 10.66 & 217.60 & 199.69 & 1770.21 & 1620. & 910.47 & 885.17 \\
\hline $\mathrm{T} 2$ & 83.98 & 82.26 & 22.16 & 20.58 & 26.66 & 24.00 & 22.33 & 20.33 & 221.71 & 211.37 & 2351.91 & 2152.48 & 1205.70 & 1165.05 \\
\hline $\mathrm{T} 3$ & 81.24 & 75.38 & 19.91 & 18.87 & 21.66 & 22.66 & 26.00 & 23.00 & 315.82 & 295.58 & 2813.41 & 2375.92 & 1727.81 & 1406.16 \\
\hline $\mathrm{T} 4$ & 79.52 & 72.81 & 19.71 & 18.47 & 23.00 & 21.33 & 27.33 & 24.66 & 342.11 & 322.94 & 2670.21 & 2311.87 & 1490.79 & 1335.61 \\
\hline LSD 5\% & 1.39 & 1.47 & 1.69 & 1.80 & 0.66 & 1.33 & 1.00 & 1.66 & 1.00 & 2.05 & 6.59 & 5.36 & 7.39 & 8.39 \\
\hline
\end{tabular}

T0 control (Nile water); T1 (salt water 9000 ppm); T2 (salt water 18000 ppm);

T3 (salt water $24000 \mathrm{ppm}$ ) and T4 (salt water (36000 ppm).

- At 180 days of plant age: Data shown in Table (6) indicated that, salt water irrigation levels i.e., 9000, 18000, 24000 and $36000 \mathrm{ppm}$ significantly increased plant height, root length, number of leaves/plant, number of branches, fresh weight of roots g/plant, fresh weight of shoots g/plant and dry weight of shoots g /plant when compared with control treatment (river water) at 180 days of plant age during 2017 and 2018 seasons. Salt water at $9000 \mathrm{ppm}$ irrigation level gave the highest value followed by 18000 , followed by control followed by 24000 and 36000 ppm saltwater, with plant height, root length at 180 days of plant age during 2017 and 2018 seasons. Also, in the same time number of leaves 
were increased with $18000 \mathrm{ppm}$ of saltwater irrigation level followed by $9000 \mathrm{ppm}$, followed by $24000 \mathrm{ppm}$, followed by $36000 \mathrm{ppm}$ when compared with the control (Nile water) at 180 days of plant age during 2017 and 2018 seasons. While number of branches /plant reached the highest value with salt water, followed by 36000 ppm, followed by 18000 ppm, followed by 9000 ppm salt water irrigation water when compared with the control at 180 days of plant age during 2017 and 2018 seasons. In addition, root fresh weight $\mathrm{g} / \mathrm{plant}$ reached the highest value with 36000 ppm salt water followed by other salt water levels at 180 days of plant age during first and second seasons. Furthermore, shoots fresh weight g/plant and shoots dry weight $\mathrm{g}$ /plant significantly increased with $24000 \mathrm{ppm}$ salt water, followed by 18000 ppm salt water, followed by 36000 ppm salt water, followed by $9000 \mathrm{ppm}$ salt water when compared with the control at 180 days of plant age during 2017 and 2018 seasons.

$\mathrm{NaCl}$ is a dual stressor, as it challenges osmotic regulation and sodium is toxic to enzyme systems. Salt marsh halophytes cope with salt by excluding entry into roots, sequestering salts intracellularly (leading to succulence), and excreting salt via glands, usually on leaf surfaces. One succulent, Batismaritima, continually drops its older salt-laden leaves, which are then washed away by the tide. 
Table (6): Effect of irrigation by salt water levels on some growth characteristics of Salicornia plants at 180 days of plant age during 2017 and 2018 seasons

\begin{tabular}{|c|c|c|c|c|c|c|c|c|c|c|c|c|c|c|}
\hline Charach. & $\begin{array}{r}\text { plant l } \\
\mathrm{Cl}\end{array}$ & height, & Root I & $\begin{array}{l}\text { length, } \\
\text { in }\end{array}$ & $\begin{array}{r}\text { Num } \\
\text { leaves }\end{array}$ & $\begin{array}{l}\text { n. of } \\
\text { splant }\end{array}$ & $\begin{array}{r}\mathrm{Nu} \\
\text { branch }\end{array}$ & $\begin{array}{l}\text { of } \\
\text { plant }\end{array}$ & $\begin{array}{r}\text { Roots (fr } \\
\qquad / \mathrm{F}\end{array}$ & h weight) & Shoot (fr & $\begin{array}{l}\text { hl weigh) } \\
\text { nt }\end{array}$ & Dry weig & $\begin{array}{l}\text { of shoots } \\
\text { int }\end{array}$ \\
\hline Treatment & 2017 & 2018 & 2017 & 2018 & 2017 & 2018 & 2017 & 2018 & 2017 & 2018 & 2017 & 2018 & 2017 & 2018 \\
\hline T0 & 86.11 & 81.22 & 21.06 & 19.69 & 16.00 & 14.33 & 12.66 & 10.00 & 121.78 & 115.25 & 710.78 & 670.74 & 310.87 & 282.71 \\
\hline $\mathrm{T} 1$ & 92.71 & 87.12 & 23.44 & 22.78 & 21.33 & 18.66 & 13.33 & 11.66 & 139.69 & 132.78 & 760.39 & 712.59 & 325.33 & 291.25 \\
\hline $\mathrm{T} 2$ & 86.12 & 81.36 & 20.90 & 19.85 & 23.66 & 21.00 & 21.00 & 19.33 & 130.34 & 124.69 & 890.87 & 835.34 & 451.39 & 410.66 \\
\hline $\mathrm{T} 3$ & 76.38 & 72.78 & 19.69 & 17.50 & 20.00 & 18.33 & 23.66 & 20.33 & 161.39 & 152.87 & 899.33 & 841.27 & 461.36 & 435.91 \\
\hline $\mathrm{T} 4$ & 76.42 & 71.39 & 20.11 & 17.60 & 19.33 & 17.66 & 22.33 & 21.66 & 175.65 & 164.39 & 851.25 & 798.65 & 436.87 & 410.50 \\
\hline LSD 5\% & 1.39 & 1.55 & 1.25 & 1.69 & 1.00 & 1.33 & 0.66 & 1.00 & 2.36 & 2.25 & 2.13 & 3.65 & 4.36 & 4.87 \\
\hline
\end{tabular}

T0 control (Nile water); T1 (salt water 9000 ppm); T2 (salt water 18000 ppm);

T3 (salt water $24000 \mathrm{ppm}$ ) and T4 (salt water (36000 ppm).

III-Effect of irrigation by salt water levels on yield and yield components of Salicornia plants:-

Data in Table (7) indicate that, different salt water levels i.e., 9000 ppm, 18000 ppm, 24000 ppm and 36000 ppm significantly increased Salicornia economic yield /plant, biological yield /plant and number of seeds / g with increasing salt water levels during 2017 and 2018 seasons. In this respect, the level of $36000 \mathrm{ppm}$ salt irrigation water showed the highest value when compared with the control during both seasons. 
In this respect, the obtained increased in yield and yield components could be considered beneficial but would also be ecologically relevant (Khan et al. 2000).Increases succulence of plant so that ions accumulate in vacuoles; but ions accumulation decreased with more increases in salinity (Khan et al. 2001).

Table (7): Effect of irrigation by salt water levels on some growth characteristics of Salicornia plants at 180 days of plant age during 2017 and 2018 seasons

\begin{tabular}{|c|c|c|c|c|c|c|}
\hline \multirow{2}{*}{\begin{tabular}{|} 
Tharach. \\
Treatment
\end{tabular}} & \multicolumn{2}{|c|}{ Economic yield (kg/plant) } & \multicolumn{2}{c|}{ Biological yield (kg/plant) } & \multicolumn{2}{c|}{ Number of seeds/g } \\
\cline { 2 - 7 } & 2017 & 2018 & 2017 & 2018 & 2017 & 2018 \\
\hline \hline T0 & 8.245 & 9.240 & 30.15 & 40.15 & 55.00 & 56.33 \\
\hline T1 & 10.475 & 10.420 & 45.15 & 46.39 & 50.33 & 51.66 \\
\hline T2 & 11.452 & 11.230 & 50.26 & 52.16 & 49.66 & 48.00 \\
\hline T3 & 12.302 & 12.378 & 53.18 & 56.59 & 48.00 & 47.33 \\
\hline T4 & 14.102 & 14.568 & 69.25 & 72.39 & 46.33 & 46.00 \\
\hline LSD 5\% & 0.635 & 0.525 & 2.125 & 3.26 & 2.00 & 1.33 \\
\hline \hline
\end{tabular}

T0 control (Nile water); T1 (salt water 9000 ppm); T2 (salt water 18000 ppm); T3 (salt water 24000 ppm) and T4 (salt water (36000 ppm).

- Salt concentration in soil during experiment life time: In Table (8) data indicated that, different salt irrigation water levels i.e., 9000, 18000, 24000 and $36000 \mathrm{ppm}$ salt water)decreased salt concentration(ppm)in soil at 80, 120, 150 and 180 days of plant age during 2017 and 2018 seasons. The 
control gave the lowest valueforsoil salt concentration at different plant stages during the two growing seasons. Increasing of salt water levels increased different salt accumulations in soil attributed to the salt water percentage during plant life time in both seasons. Meanwhile, Salicornia plants is a good phytoremediator for the salt from the soil. Also, increasing of salt percentage by increasing salt water percentage during plant life time increased growth characteristics for shoots and roots during different stages it were mentioned in Tables 3,4,5,6 and 7. In addition, growing Salicornia plants in salt water levels increased yield and yield components was mentioned in Table 8.In this respect from the abovementioned Salicornia plants it is a good phytoremediator for the salts from the soil because they are able to take up water by maintaining a high osmotic potential through the accumulation of Inorganic ions. increasing salt levels in Salicornia significantly in germination rates, for salinity levels above $50 \%$ seawater concentration. Salicornia also, used as traditional medicine treating hypertension, cephalalgia and scurvy In Korea, it is used in the treatment of constipation, obesity, diabetes and cancer Shabala, 2013).Here, the estimated $\mathrm{NaCl}$ removal ranged between 2 and 6 ton of salt per hectare per year. It should be commented though that the use of halophytes as a desalinization tool cannot be guaranteed in all cases, as their productivity may be significantly affected not only by salinity but also by other environmental conditions (Shabala, 2013). These accumulated elements in soil and water bodies can cause a risk to humans 
and other living organisms (Khan et al., 2010). A clean-up of these contaminated soils is needed but challenging, especially in terms of the cost, when conventional salts tools such as soil incineration or washing are used (Sheoranet al., 2011 and Wuana \& Okieimen, 2011). The use of hyper-accumulating plants may reduce this cost dramatically. Salicornia is a halophytic plant show an ability to grow in those saline areas and are widely advocated for phytoremediation purposes such as phytoextraction or phytostabalization (Lutts et al., 2004 and Manousaki \& Kalogerakis, 2011). Salicornia is mulled to be the right candidate for reclamation of barren lands, salt flats, and sea shores. In short, they can be deemed for seawater agriculture. It is suggested that as global warming threatens to submerge more landmass, and freshwater is depleting, a shift to saline crop might be a viable option (Katschnig et al. 2013). Few plants can tolerate excess salt and among them few are edible. In this context, Salicornia seems to be a right candidate for cultivation to produce more harvestable biomass (Singh et al., 2014). 
Table (8): Effect of Salt water irrigation levels on salt concentration ppm in soil at different period of experimental time during 2017 and 2018 seasons

\begin{tabular}{|c|c|c|c|c|c|c|c|c|}
\hline \multirow{3}{*}{$\begin{array}{c}\text { Charach. } \\
\text { Treatment }\end{array}$} & \multicolumn{8}{|c|}{ Soil Salt concentration(ppm) } \\
\cline { 2 - 9 } & $\begin{array}{c}\mathbf{8 0} \\
\text { days }\end{array}$ & $\begin{array}{c}\mathbf{1 2 0} \\
\text { days }\end{array}$ & $\begin{array}{c}\mathbf{1 5 0} \\
\text { days }\end{array}$ & $\begin{array}{c}\mathbf{1 8 0} \\
\text { days }\end{array}$ & $\begin{array}{c}\mathbf{8 0} \\
\text { days }\end{array}$ & $\begin{array}{c}\mathbf{1 2 0} \\
\text { day }\end{array}$ & $\begin{array}{c}\mathbf{1 5 0} \\
\text { days }\end{array}$ & $\begin{array}{c}\mathbf{1 8 0} \\
\text { days }\end{array}$ \\
\hline \hline T0 & 10150 & 8100 & 6250 & 1050 & 12250 & 8390 & 6270 & 2150 \\
\hline T1 & 10250 & 8300 & 5580 & 1410 & 12580 & 9460 & 6340 & 2360 \\
\hline T2 & 10680 & 9290 & 6350 & 2320 & 13370 & 10220 & 8530 & 3360 \\
\hline T3 & 10390 & 8390 & 6500 & 2540 & 13450 & 10550 & 8620 & 3580 \\
\hline T4 & 10150 & 8630 & 6690 & 3710 & 13680 & 10690 & 8790 & 3760 \\
\hline LSD & 15.25 & 11.36 & 12.29 & 10.38 & 10.12 & 11.24 & 11.38 & 8.37 \\
\hline $00.5 \%$ & 15 & &
\end{tabular}

T0 control (Nile water); T1 (salt water 9000 ppm); T2 (salt water 18000 ppm); T3 (salt water $24000 \mathrm{ppm}$ ) and T4 (salt water (36000 ppm).

\section{CONCLOUSION}

Applying of salt water levels i.e., 9000, 18000, 24000 and 36000 ppm of mixed fresh water and compared with Tap water (control) increased Salicornia growth and development of growth performance at different plant stage. In this context, applying of salt levels increased yield and yield components in Salicornia plants and decreased salt percentage in soil. Trials and nutritional assessments on it for human edibility are novel. As outlined in above sections, Salicornia both have its pros and cons as a food candidate. Additional research might better illuminate on its relevance for consumption. In this regard, some significant areas pertaining to it have been discussed. 
Also, Salicornia is touted as a 'secondary vegetable', 'famine food' and 'plant for future'. Despite multiple evidences of its health benefits it languishes as a mere marsh plant. As food insecurity looms large, such nutrition sources should not be wasted. Further, saline habitats have low agronomic relevance, so this halophyte can be cultivated to make better use of them and as a good indicator for salt stress conditions.

\section{REFERENCES}

Aghaleh, M., Niknam, V., Ebrahimzadeh, H. and Razavi, K., (2009): Salt stress effects on growth, pigments, proteins and lipid peroxidation in Salicornia persica and S.europaea. Biol. Plant. 53, 243-248.

Ashour, N., Arafat, S.M., El-Haleem, A.A., Serag, M., Mandour, S., Makki, B., (1999): Growing halophytes in Egypt for forage production and desertification control. Bulletin of National Research Center (Cairo) 4 (3), 349-360.

Barkla, B.J., Vera-Estrella, R., Camacho-Emiterio, J., Pantoja, O., (2002): $\mathrm{Na}+\mathrm{H}+$ exchange in the halophyte

Mesembryanthemumcrystallinum is associated with cellular sites of Na+storage. Funct. Plant Biol. 29, 1017-1024.

Barrett-Lennard, E.G., (2002): Restoration of saline land through revegetation. Agri- cultural Water Management 53, 213-226.

Black, C. A. (ed.) (1965): Method of Soil Analysis, Part 2, Chemical and Microbiological Properties, American Society of Agronomy, Inc, Publisher, Madison, Wisconsin USA. 
Journal of Environmental Sciences (JES)

Institute of Environmental Studies and Research, Ain Shams University

Abdu et al.

Blits, K.C., Gallagher, J.L., (1990): Effect of $\mathrm{NaCl}$ on lipid content of plasma membranes isolated from roots and cell suspension cultures of the dicot halophyte Kosteletzkya virginica (L.) Presl. Plant Cell Rep. 9, 156-159

Eganathan, P.S.R, Subramanian, H.M., Latha, R., Srinivasa Rao, C., (2006): Oil analysis in seeds of Salicornia brachiata. Industrial Crops and Products 23, 177-179.

FAO, (2012): FAO Statistical Year Book 2012, World Food and Agriculture. Food and Agriculture Organization of the United Nation, Rome, p. 366. http://www. fao.org/docrep/015/i2490e/i2490e00.htm

Flowers, T.J., Troke, P.F., Yeo, A.R., (1977): The mechanism of salt tolerance in halo- phytes. Annual Review of Plant Physiology 28, 89-121.

Flowers, T.J.andColmer, T.D., (2008): Salinity tolerance in halophytes. New Phytologist 179, 945-963

Ghassemi, F., Jakeman, A.J. and Nix, H.A., (1995): Salinisation of Land and Water Resources: Human Causes, Management and Case Studies. University of New South Wales Press, Sydney, Australia.

Glenn, E.P., Brown, J.J., Blumwald, E., (1999): Salt tolerance and crop potential of halophytes. Crit. Rev. Plant Sci. 18, 227-255.

Greenway, H and Munns, R., (1980): Mechanisms of salt tolerance in nonhalophytes. Annu. Rev. Plant Physiol. 31, 149-190.

Isca, V.M.S., Seca, A.M.L., Pinto, D.C.G.A., Silva, H., Silva, A.M.S. (2014): An overviewof Salicornia genus: the phytochemical and pharmacological profile. Nat. Prod.2, 145-176.

Jaleel, C.A., Manivannan, P., Sankar, B., Kishorekumar, A., Panneerselvam, R., (2007): Calcium chloride effects on salinity-induced oxidative stress, proline metabolism and indole alkaloid accumulation in Catharanthus roseus. Competes Rendus Biol. 330, 674-683. 
Katschnig D, Broekman R, Rozema J. (2013): Salt tolerance in the halophyte Salicornia dolichostachya Moss: growth, morphology and physiology. Environ Exp Bot. 2013;92:32-42. doi: 10.1016/j.envexpbot.2012.04.002. [CrossRef] [Google Scholar] [Ref list]

Khan M.A., Gul, B. and Weber, D.J. (2001): Effect of salinity on the growth and ion content of salicornia rubra Soil Sci. Plant Anal, 32(17-18), 2965-2977.

Khan, M.A., Unger, I.A. and Showalter, A.M. (2000): The effect of salinity on the growth, water status, and ion content of a leaf succulent perennial halophyte, Suaedafruticosa (L.) Forssk. J. of Arid Environments, 45, 73-84.

Khan, S., Hesham, A.E.L., Qiao, M., Rehman, S., He, J.Z., (2010): Effects of $\mathrm{Cd}$ and $\mathrm{Pb}$ on soil microbial community structure and activities. Environmental Science and Pollution Research 17, 288-296.

Lambert, M. and Turner, J., (2000): Commercial Forest Plantation on Saline Lands. CSIRO Publishing, Collingwood, pp. 198.

Lutts, S., Lefe'vre, I. Delpe_re_e, C., Kivits, S. Dechamps, C. Robledo, A., Correal, E. (2004): Heavy metal accumulation by the halophyt especies Mediterranean saltbush. Journal of Environmental Quality 33, 1271-1279.

Manousaki, E. and Kalogerakis, N. (2011): Halophytes present new opportunities in phytoremediation of heavy metals and saline soils. Industrial and Engineering Chemistry Research 50, 656-660

Munns, R., (2005): Genes and salt tolerance: bringing them together. New Phytologist 167, 645-663.

Munns, R. and Tester, M., (2008): Mechanisms of salinity tolerance. Annu. Rev. Plant Biol. 59, 51-681. 
Nie, L., Feng, J., Fan, P., Chen, X., Guo, J., Lv, S., et al., (2015): Comparative proteomics of root plasma membrane proteins reveals the involvement of calciumsignalling in $\mathrm{NaCl}$-facilitated nitrate uptake in Salicornia europaea. J. Exp. Bot.66, 4497-4510.

Parida, A.K., Das, A. B. (2005): Salt tolerance and salinity effects on plants: a review. Ecotoxcol. Environ. Safety 60, 324-349.

Parks, G.E., Dietrich, M.A., Schumaker, K.S., (2002): Increased vacuolar $\mathrm{Na}+\mathrm{H}+$ exchange activity in Salicornia bigelovii Torr. in response to $\mathrm{NaCl}$. J. Exp. Bot.53, 1055-1065

Patel, S., (2016): Salicornia: evaluating the halophytic extremophile as a food and a pharmaceutical candidate. 3 Biotechnol. 6, 104.

Piper, C. (1950): Soil and Plant Analysis. International Public Inc., New York

Pessarakli, M., Szabolics, I., (1999): Soil salinity and sodicity as particular plant/crop stress factors. In: Pessarakli, M. (Ed.), Handbook of Plant and Crop Stress., second edition. Marcel Dekker, New York, NY, pp. 1-16.

Roy, S.J., Negrao, S., Tester, M., (2014): Salt resistant crop plants. Curr. Opin.Biotechnol. 26, 115-124.

Shabala, S., (2013): Learning from halophytes: physiological basis and strategies to improve abiotic stress tolerance in crops. Ann. Bot $112,1209-1221$.

Shabala, S. and Mackay, A. (2011): Ion transport in halophytes. Adv. Bot. Res. 57,151-199.

Sheoran, V., Sheoran, A., Poonia, P., (2011): Role of hyper accumulators in phytoextraction of metals from contaminated mining sites: a review. Critical Reviews in Environmental Science and Technology 41, 168-214.

Silica, and the effect of particle solubility. Environ. Sci. Technol. 40, 43744381. 
Singh, D., Buhmann, A.K., Flowers, T.J., Seal, C.E., Papenbrock, J. (2014): Salicornia as acrop plant in temperate regions: selection of genetically characterized ecotypes and optimization of their cultivation conditions. AoB Plants 6, plu071.

Snedecor, G.W. and Cochran, W.G. (1980): Statistical Methods. $7^{\text {th }}$ Ed. Iowa State Univ. Press Ames. Iowa, USA.

Song, J., Fan, H., Zhao, Yu., Du, X., Wang, B. (2008): Effect of salinity on germination, seedling emergence, seedling growth and ion accumulation of a euphyllophytes to improve abiotic stress tolerance in crops. Ann. Bot 112, 1209-1221.

Tobe, K., Li, X., Omasa, K. (2004): Effects of five different salts on seed germination and seedling growth of Haloxylonammodendron (Chenopodiaceae). Seed Sci.Res. 14, 345e353.

Ventura, Y., Wuddineh, W.A., Myrzabayeva, M., Alikulov, Z., KhozinGoldberg, I., Shpigel, M., Samocha, T.M., Sagi, M. (2011): Effect of seawater concentration on the productivity and nutritional value of annual Salicornia and perennial Sarcocornia halophytes as leafy vegetable crops. Scientia Horticulturae 128, 189-196.

Wuana, R.A., Okieimen, F.E. (2011): Heavy metals in contaminated soils: a review of sources, chemistry, risks and best available strategies for remediation. ISRN Ecology 2011, 1-20.

Zhu, J.K. (2001): Plant salt tolerance. Trends Plant Sci. 6, 66-71. 


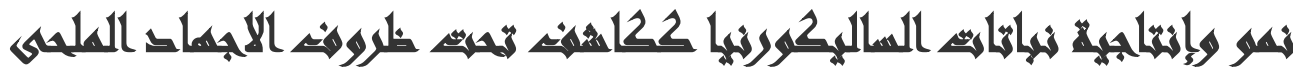

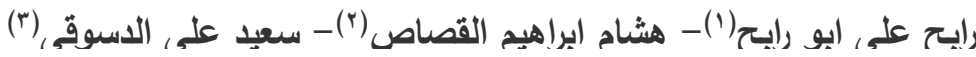

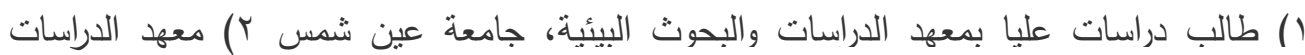 \\ والبحوث البيئية، جامعة عين شمس بات كلية الزراعة، جامعة بنها
}

\section{المستصلص}

أصبح الإجهاد الملح، أكبر تحديا للإنتاج الزراعي، والتتمية. نم اجراء تجربتان حقليتان في،

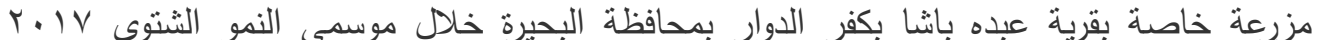

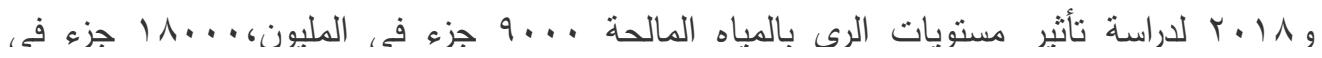

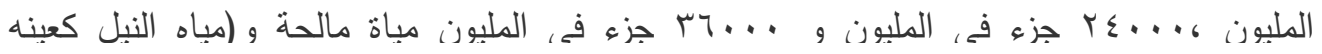
ضابطه) علم، نمو وإنتاجية وتراكم الملح في ألاجزاء النباتية المختلفة من نباتات الساليكورنيا المزروعة النياء

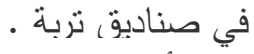

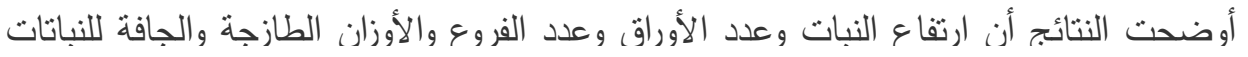

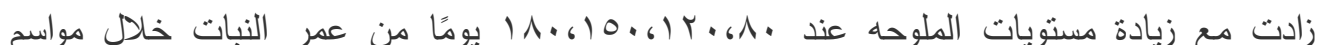

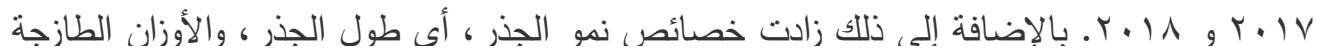

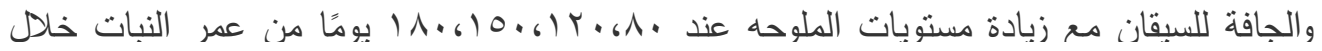

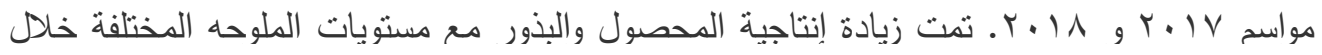

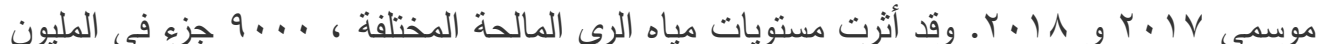

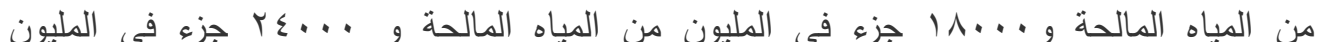

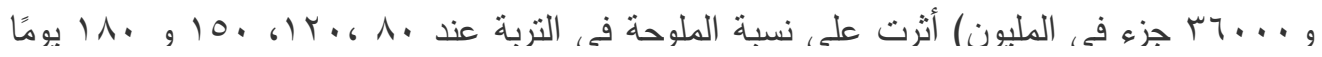

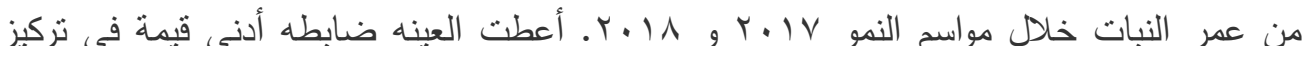

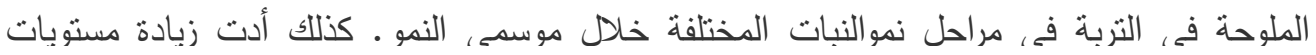

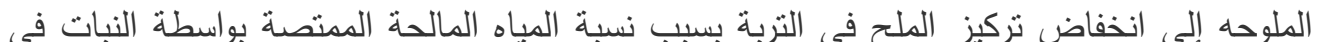

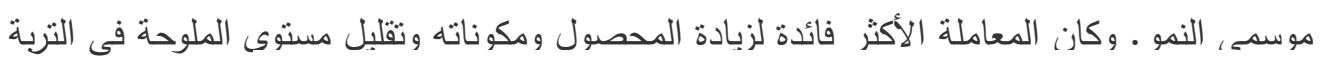

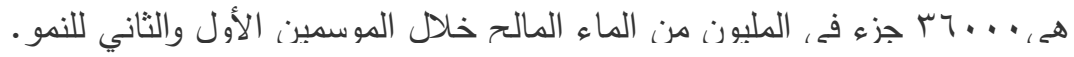
الكلمات الداله: نبات الساليكورنيا، الملوحه، المحصول، مراحل النمو . لماءل 